\title{
THE PATERNAL POWER IN JAPANESE LAW.
}

The Restoration of 1868 marks the beginning of a new era in the history of Japan. The old feudal system was completely overthrown, and with it have passed away most of the ancient laws and customs. But it is in the domain of family law that this change has been accomplished most slowly, and it is noteworthy that the book on the law of persons in the new Civil Code was among the last to be compiled and promulgated.

The family life and organization of the Japanese presents a striking resemblance to that of the Chinese and of the Romans. It was, and to a great extent is to-day, essentially a patriarchal one, and forms the basis of the entire social structure. Although under the influence of the doctrines of the three great systems of law, the English, the French and the German, the basis of Japanese society will necessarily be shifted from the family to the individual, it will require many decades to accomplish fully. this result.

In the Japanese family a sharp distinction is drawn between agnatic and cognatic relationship, and always in favor of the former. This fact is strikingly brought out in the punishments to be inflicted for assaults upon, or abusive language towards, relatives, which vary according as such relatives are agnates or cognates. ${ }^{1}$

There exists a strong sense of the unity of the family, a state of facts fostered in many ways by the law. Thus, under the Penal Code of 1871-73, relatives are not punishable for aiding each other's escape when accused of crime, and, on the other hand, severe punishments are to be inflicted upon persons bringing an information against a parent or paternal grandparent-and this whether the charge be true or false." "Indeed," as Mr. Kazuo Miura says, "harmony and co-operation are characteristic features of a Japanese family."

The honke, or principal house, may have a number of branches, but the heads of the latter are always subject to the power of the $k o s h u$ or head of the principal house. The persons living in the honke and subject to the power of the koshu are called kazoku.

1Longford. "Penal Codes," pp. 64, 69.
2Ibid, p 76.

3" Th: Japanese Family," p. 672. 
Unlike in the Roman law the distinction was formerly made in public law between a koshu and a kazoku, the koshu acting as representative of his entire louse. ${ }^{2}$

The power of the koshu is exercised not alone over his descendants, but also over his sisters and younger brothers and their descendants, as well as over his ascendants when his father or grandfather has retired, like another Laertes, from the management of the household affairs, as inkz'o. But the power over such ascendants is more limited and is hardly susceptible of legal determination. ${ }^{2}$

As in the Roman law, the only distinction is between a person sui juris and one alieni juris, and hence a minor may be a koshu, a guardian being appointed during his minority. But a branch-family can be established only by a male who has attained his majority. ${ }^{3}$

The succession to the family headship is generally- from eldest son to eldest son, but the koshu, may, at his discretion, create a branch-family with the eldest son at its head, and allow a jounger son to succeed him as koshu. ${ }^{4}$

The power of the koshu is acquired over children who are the offspring of a valid marriage of himself or any of his kavoku; and over children which have been legitimated by the subsequent marriage of their natural parents. ${ }^{\circ}$ The relationship of koshu and kazoku can also be established by the acknowledgment of a natural child, provided that the consent of the public authorities of the district where the mother resides be first obtained.?

The practice of adoption is of high antiquity and great importance in Japanese life. For most purposes the adopted child is entitled to all the rights and subject to all the duties of a natural child. But when a child has been adopted as successor to the family hearlship of the adopter's house, the adoptive father can not transfer such clild to another. ${ }^{8}$

"Weipert, "Familienrecht," p. 89. So in China the kia-tckang alowe has the right of suffrage in the municipal assembles.

2Weipert, p. 39.

${ }^{3}$ Ibid, p. 89.

"Wigmore, "Law in Old Japan," part V., p. 8s. In rarc instances was a female allowed to become the head of a family. Weipert. p. 90.

sWeipert, p. rog, Cf. Civil Code, art. 91.

Weipert, p. 109, Cf. Civil Code, artt. ro3. 104.

TWeipert, p. I09. Under the Ministerial Decree of January 22, IS87, such child is placed in the position of a shoshi (i. e. a child of a concubine). Ibid, Cf. Civil Code, arts. 98, 103.

'Weipert. pp. I15, I16. Cf. Civil Code. arts. 134. 35 . Morris, “-Aroption in Japan," in Yale Law Journal, Vol. IV (1S95), No. 2. passim. Arrogation seems not to exist. 
The koshu until within recent times had the jus vitae necisque over his kazoku. This was, however, not a mere arbitrary right, but could be exercised only in the execution of his judicial decisions as family chief. Any other exercise of his power would have subjected him to the death penalty. ${ }^{1}$ By the Krvamporitsu (art. 49) parents were given the right to kill a daughter discovered in immoral relations with a man other than the one to whom she was betrothed. $^{2}$ Under the Penal Codes of $187 \mathrm{I}-3$ infanticide is punishable in the same manner as any other intentional killing of a relative, and the wilful murder of a child, by a grandfather or father, is punishable by penal servitude for three years. ${ }^{3}$ So also the abandonment of young children is punishable."

Whether the paterfamilias had the right to sell his child into servitude is part of the larger question whether slavery ever existed in Japan. Weipert," basing his assertion on the Kreamporitsu (art. 46), thinks that such sales were formerly allowed. ${ }^{\circ}$ Under the Penal Codes of $187 \mathrm{r}-3$, the consent of a daughter is required in selling her for purposes of prostitution.?

Under the Penal Codes of $1871-3$, a parent or grandparent shall be liable to no penalty for beating a child, however severe the chastisement, unless death results, by reason of such excessive punishment. $^{8}$ But already under the Kwamporitsu (art. 65) children were given a right of complaint to the tribunals against unjust treatment by parents. ${ }^{\circ}$ By the new Civil Code, the father and mother are given the right of chastising their children; "nevertheless, an excessive correctional act cannot be done" (art. I5I). The father and mother are given the right to apply to the Local Court in order to have the child who has been guilty of ill-behavior, confined in a house of correction or reformatory institution for a period not exceeding six months. The court shall rule after hearing the Public Procurator, and "the father, mother or the child can bring a complaint against such rule" (art. I52).

Under the Japanese system as existing until the adoption of the Civil Code, marriage was neither a contract nor a religious institu-

'Friedrich, "Zum Japanischen Recht," p. 366.

2Weipert, p. II7. Cf. I. Burgundionum, XXXV, 2, 3..

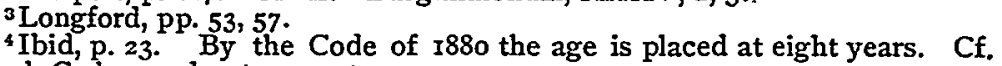
French Code penal, arts. 349 et seq.

5P. 117.

${ }^{\circ} \mathrm{Cf}$. Miura, p. 670 .

'Weipert, p. II7.

${ }^{8}$ Longford, p. 67.

${ }^{9}$ Weipert, p. I 7 . 
tion, but a handing over of the bride by her own family to that of her husband." Under the Code, a child can not enter into a marriage without the permission of both parents, or of one of them, when the other is unable to express his intent (art. 38). And if both parents be dead or incapacitated, then the "permission of the grandfather and grandmother in the house shall be obtained (art. 39). No age under which this is necessary is provided for (cf. art. 40). It is worthy of note that the Japanese code has not adopted the actes respectueux of the French law, and makes no provision for cases of disagreement between the two parents or grandparents. If the requisite permission has not been obtained, a nullification of the marriage can be demanded by any person who should have given or received such permission (art. 60).

Children are under the obligation of aiding their indigent parents, and a neglect of this duty was punishable under the Penal Code of I87I by imprisonment of two years, a punishment which was reduced by the Code of 1880 to confinement for a term of from fifteen days to six months and a fine of from two to twenty yen. ${ }^{2}$

- As in China the worship of ancestors forms an essential part of the national religious cult. Elaborate rules and ceremonials are prescribed concerning sacrifice and mourning, a failure to observe which is punishable as a crime. ${ }^{3}$

Originally the control of the koshu over all the property acquired by those under his power was absolute. He owned and disposed of the family property, but on the other hand. he was responsible for all the acts of his kazoku. These strict rules weregradually relaxed and the kasoku was allowed to have a peculizm (kimei-zaisan) which, as in Rome. was liable for the debts of the kazoku. In fact, in his relations to persons other than his koshu, he came to be regarded as sui juris, and could even bring suits in his own name. ${ }^{*}$ This entire system of property relations has now been done away with, and replaced by one similar to that of the European codes. Thus the father has the administration (art. I53) and the usufruct of the property of the minor child (art. $15^{6}$ ), except of the child's earnings in a business carried on apart from his father (arts. 125, 155). The child has the absolute ownership of property acquired by succession, donation, or legacy (arts. 135, I55).

${ }^{1}$ Grigsby, "Legacy of Iyeyas," p. I35.

2Weipert, p. I 7 .

3Longford, p. 29.

${ }^{4}$ Grigsby, p. 132: Weipert, p. S 
The authority of the koshu ceases:

I. By his death. The power passes, as a rule, to his eldest son ; ${ }^{1}$

2. Over his female kazoku, by giving them in marriage;

3. By giving his child in adoption. Here the duties of mourning, sacrifice, and maintenance, however, remain unaffected ${ }^{2}$

4. By the kando (or kiuri), the old Japanese form of emancipation. But, unlike the Roman emancipation which was often the reward of filial devotion, the kando is used only in case the child is an irredeemably bad character. The kando operated as a complete severance of all ties and the person thus emancipated is thenceforth not regarded as a cognate. ${ }^{3}$

Under the Civil Code provision is made for ordinary emancipation, and marriage emancipates the child "as of course" (art. 2I3).

Bibliography: Civil Code of Japan. Law of Persons. Official Translation. Tokio, 1892; Friedrich, Karl, Zum Japanischen Recht (In Zeitschrift für vergleichende Rechtswissenschaft, Band $\mathrm{X}$ ); Grigsby, W. E., The Legacy of Iyeyas (In Transactions of the Asiatic Society of Japan, Vol. II.). Yokohoma, r884; Longford, Joseph H., A Summary of the Japanese Penal Codes (In Transactions of the Asiatic Society of Japan,.Vol. V., Part II.). Yokohama, I887; Miura, Kazuo, The Japanese as Compared with the Roman Family Law (In the New Englander, Vol. XXXVII., No. 5) ; Weipert, H., Japanisches Familien-und Erbrecht (In Mittheilungen der deutschen Gesellschaft für Natur-und Völkerkunde Ostasiens in Tokio, Band V., Heft 43). Yokohama, r8go; Wigmore, J. H., Materials for the Study of Private Law in Old. Japan (In Transactions of the Asiatic Society of Japan, Vol. XX., Supplement), Tokio, I892.

University of Texas.

Charles Henry Huberich.

IA koshu who has become an inkvo, (i. e. retired from the family headship), may at any time resume his authority. Weipert, p. II8.

${ }^{2}$ Weipert, p. IIs.

${ }^{2}$ Grigsby, p. I13; Weipert, p. I18. Cf. Longford, p' 28. 